\title{
PENGARUH RISIKO BISNIS, LIFE CYCLE DAN DIVERSIFIKASI TERHADAP STRUKTUR MODAL SERTA HUBUNGANNYA DENGAN NILAI PERUSAHAAN MANUFAKTUR DI INDONESIA
}

\author{
Septi Diana Sari \\ Fakultas Bisnis dan Teknologi Informasi, Universitas Teknologi Yogyakarta \\ E-mail: septi_diana@yahoo.com
}

\begin{abstract}
This study aims to examine the factors that affect the capital structure. The task of the financial manager is to determine the amount of capital structure to enhance shareholder value. Since the capital structure associated with firm value, this study also aimed to examine the effect of capital structure on firm value by considering the company's diversification strategy and corporate life cycle stages. By using the data obtained from the OSIRIS period 2009-2012, researchers used multiple regression test and path analysis to test the hypothesis. From the test results stated that only companies which are in the start-up phase which has a significant positive effect on the capital structure, as well as the diversification strategy has an influence on the capital structure of the company's capital structure with a sequence of related diversification > unrelated diversification > single segment. But when regressed diversification strategy with corporate values, only a single segment strategy and related diversification which significantly affect the value of the company, as well as the positive effect of capital structure on firm value. Most of the results of this study can be explained by the signaling effect and the pecking order theory.
\end{abstract}

Keywords: Risiko Bisnis, Firm Life Cycle, Diversifikasi, Struktur Modal, Nilai Perusahaan

\section{PENDAHULUAN}

Manajer berperan penting dalam upaya menjaga kelangsungan usaha, salah satu upaya yang dapat dilakukan manajer keuangan adalah memperoleh dana yang diperlukan dengan biaya yang minimal atau biaya yang dapat ditekan serta syarat-syarat yang paling menguntungkan (Suwarto dan Ediningsih 2002). Sumber dana perusahaan dapat berasal dari internal, berupa laba ditahan maupun eksternal yaitu dari hutang dan ekuitas. Keputusan pendanaan keuangan perusahaan akan sangat menentukan kemampuan perusahaan dalam melakukan aktivitas operasi perusahaan dan juga terhadap resiko perusahaan itu sendiri. Sehingga keputusan pendanaan akan berpengaruh 


\section{Septi Diana Sari}

terhadap posisi keuangan perusahaan yang berujung pada nilai perusahaan dimata investor maupun calon investor.

Campuran hutang dan ekuitas yang digunakan perusahaan untuk membiayai operasinya disebut sebagai struktur modal (Abor 2007). Struktur modal optimal dapat terwujud ketika perusahaan dapat meminimalkan biaya modal dan memaksimalkan harga sahamnya (Gaius dalam Akintoye 2008). Keinginan untuk mewujudkan struktur modal yang optimal sudah menjadi perhatian para praktisi dan akademisi. Beberapa penelitian di Amerika dan Eropa menunjukan bahwa faktor yang mendorong keputusan struktur modal perusahaan adalah keinginan untuk mencapai dan mempertahankan fleksibilitas keuangan, sehingga perusahaan mampu menghindari kesulitan keuangan dalam menghadapi shock yang bersifat negatif dan untuk menyiapkan dana investasi ketika mempunyai kesempatan yang menguntungkan (Gamba \& Triantis 2008).

Terdapat beberapa variabel yang dapat menjelaskan variasi kebijakan pendanaan perusahaan diantaranya size, tangibility, market-to-book ratios, dan profitability (Frank \& Goyal 2009; Parsons \&Titman 2008). Kahl, Lunn \& Nilson (2012) menyatakan perusahaan dengan biaya tetap yang tinggi memiliki profitabilitas yang lebih tinggi dan hutang yang lebih sedikit dibandingkan perusahaan dengan biaya tetap yang rendah. Alonso (2000) dalam penelitiannya dengan menggunakan sampel perusahaan-perusahaan di Spanyol menunjukan bahwa level diversifikasi perusahaan berpengaruh negatif terhadap kebijakan hutang perusahaan, bukti empiris tersebut konsisten dengan efek pendisiplinan dari keputusan hutang, dimana peningkatan pengawasan keputusan yang diambil perusahaan oleh kreditur menurunkan adanya kemungkinan manajer mengambil strategi yang dapat menurunkan nilai perusahaan.

Risiko bisnis merupakan salah satu faktor yang mempengaruhi keputusan manajer dalam menentukan struktur modal perusahaan. Menurut Brigham dan Hauston (2005), faktorfaktor yang mempengaruhi struktur modal yaitu: risiko bisnis, posisi pajak, fleksibilitas, keuangan dan konservatisme atau agresivitas managemen. Fama \& french (2005) menunjukan bahwa karakteristik pertumbuhan dan profitabilitas perusahaan merupakan

sentral keputusan pendanaan perusahaan, karena peluang pertumbuhan mengindikasikan seberapa besar kebutuhan investasi perusahaan dan profitabilitas mencerminkan tingkat kebutuhan investasi yang dapat didanai secara internal. Frielinghaus et al (2005) menyatakan bahwa tingkat rasio hutang akan berbeda-beda sesuai dengan tahapan hidup perusahaan. Tahapan siklus hidup mencakup variasi tingkat akuisisi perusahaan, level investasi awal dan re-investasi modal dan kemampuan beradaptasi dengan lingkungan yang kompetitif. karena kebutuhan pendanaan dapat berubah sesuai 
dengan perubahan kondisi perusahaan (Damodaran 2001). Dia juga menyatakan bahwa perusahaan yang sedang berkembang dan mengalami pertumbuhan yang tinggi akan menggunakan sumber dana dari ekuitas, sementara perusahaan dalam tahapan dewasa (mature firms) akan mengganti ekuitasnya dengan hutang.

Karena nilai tercipta ketika perusahaan menghasilkan return dari modal yang melebihi biaya modalnya (steward 1999), salah satu fungsi tujuan manajemen adalah memaksimumkan life stage ketika perusahaan menikmati pertumbuhan superior. Organisational life stage theory memberikan manajemen beberapa arahan (padoman) bagaimana karakteristik perusahaan berubah dari waktu ke waktu dan memberikan diagnostic tools yang menunjukan bagaimana perusahaan dapat mencapai dan mempertahankan prime life stage mereka. Manajemen yang lebih bagus harus memahami karakteristik individual life stage, kemungkinan lebih tinggi bahwa manajemen akan menggunakan atau memakai modal dengan cara tertentu sehingga perusahaan melanjutkan kinerja outperformnya dibandingkan pesaingnya (Adizes 2004).

Tujuan perusahaan dalam jangka panjang adalah mengoptimalkan nilai perusahaan dengan meminimumkan biaya modal perusahaan. Nilai perusahaan dapat diartikan sebagai ekspektasi nilai investasi pemegang saham (harga pasar ekuitas) dan/atau ekspektasi nilai total perusahaan (harga pasar ekuitas ditambah dengan nilai pasar hutang). Wahyudi \& Hartini (2004) membuktikan bahwa keputusan pendanaan berpengaruh terhadap nilai perusahaan. Berdasarkan penjelasan diatas, penelitian ini dimaksudkan untuk menganalisis faktor-faktor penentu struktur modal serta dampaknya terhadap nilai perusahaan.

\section{KERANGKA TEORITIS \& PENGEMBANGAN HIPOTESIS}

\section{Teori Struktur Modal}

Sejumlah teori telah banyak digunakan untuk menjelaskan variasi struktur modal perusahaan diantarany: (1) Agency theory yang dikemukakan oleh Jensen dan Meckling pada tahun 1976, di mana manajemen merupakan agen dari pemegang saham. Para pemegang saham berharap agen akan bertindak atas kepentingan mereka sehingga mereka mendelegasikan wewenang kepada agen. Dalam kaitannya struktur modal, biaya keagenan timbul akibat ketidak selarasan kepentingan antara pemilik dan kreditor. (2) Signalling theory adalah teori yang menerangkan suatu tindakan yang diambil manajemen perusahaan yang memberi petunjuk pada investor tentang bagaimana manajemen memandang prospek perusahaan (Brigham dan Houston 2005). Perusahaan 


\section{Septi Diana Sari}

dengan prospek yang menguntungkan akan mencoba menghindari penjualan saham dan mengusahakan modal baru dengan cara-cara yang lain, termasuk penggunaan hutang yang melebihi target struktur modal yang normal. Sebaliknya, perusahaan dengan prospek yang kurang menguntungkan akan cenderung menjual sahamnya. (3)Teori asimetri mengatakan bahwa pihak-pihak yang berkaitan dengan perusahaan tidak mempunyai informasi yang sama mengenai prospek dan risiko perusahaan. Manajer biasanya memiliki informasi yang lebih baik dibandingkan pihak luar seperti investor. Karena itu bisa dikatakan terjadi asimetri informasi antara manajer dan investor (Hanafi 2012). (4) Pecking order theory menyatakan bahwa perusahaan menyukai internal financing (pendanaan dari operasional perusahaan dengan wujud laba ditahan). Apabila diperlukan pendanaan dari luar, maka perusahaan akan memulai dengan menerbitkan sekuritas yang paling aman terlebih dahulu yaitu obligasi, kemudian sekuritas berkarakteristik opsi seperti obligasi konversi. Kemudian jika belum mencukupi, perusahaan menerbitkan saham. (5) Teori tradeoff mengemukakan perusahaan diharuskan mempertimbangkan risiko kebangkrutan antara pembiayaan dengan menggunakan hutang dengan pembiayaan melalui penerbitan saham. Perusahaan akan berhutang sampai pada tingkat hutang tertentu, dimana penghematan pajak (tax shields) dari tambahan hutang sama dengan biaya kesulitan keuangan (financial distress). Biaya kesulitan keuangan (financial distress) adalah biaya kebangkrutan (bankruptcy costs) atau reorganization, dan biaya keagenan (agency costs) yang meningkat akibat dari turunnya kredibilitas suatu perusahaan.

\section{Struktur Modal Pada Setiap Tahapan Siklus Hidup Perusahaan}

Setiap perusahaan dapat mengalami lima tahap siklus kehidupan yaitu tahap pendirian, ekspansi, pertumbuhan tinggi, kedewasaan, dan penurunan. Pada setiap tahap siklus kehidupan ini kebutuhan akan besarnya modal akan berbeda. Guna memenuhi kebutuhan tersebut perusahaan akan menggunakan strategi pendanaan berbeda pula. Secara umum pada tahap pendirian, sumber dana perusahaan banyak berasal dari pendiri perusahaan (sumber dana internal) dan utang bank. Pada tahap ekspansi, peningkatan kebutuhan dana dipenuhi dari modal ventura. Pada tahap pertumbuhan tinggi, perusahaan menjadi perusahaan publik (sumber dana eksternal). Pada tahap kedewasaan, kebutuhan dana eksternal mulai menurun karena sumber dana internal yang relatif cukup. Pada tahap terakhir, tahap penurunan, kebutuhan akan dana eksternal dan internal menurun drastic.

Perusahaan dalam tahap mature mampu melakukan pinjaman dengan lebih mudah dan lebih murah. Oleh karena itu perusahaan dalam tahap mature/ dewasa akan menggunakan pendanaan dengan hutang terlibih dahulu kemudian ekuitas. Bender \& Ward (1993) menyatakan bahwa risiko bisnis akan berkurang sepanjang tahapan hidup 
perusahaan dan menyebabkan meningkatnya risiko finansial. Hovakimian, Opler \& Titman (2001) menyatakan bahwa perusahaan sebaiknya menggunakan lebih banyak hutang untuk mendanai aset yang ada dan lebih banyak ekuitas untuk mendanai kesempatan tumbuh. Dalam konteks model tahapan hidup Adizes, perusahaan dalam tahap prime dan stable (dewasa) seharusnya menggunakan lebih banyak hutang. Penggunaan lebih banyak hutang ini dilakukan karena biaya keagenan pada tahap dewasa lebih besar sehingga hutang difungsikan untuk dapat mengurangi biaya keagenan tersebut.

$\mathrm{HI}$ : H1: Struktur modal perusahaan dalam tahap dewasa lebih besar dibandingkan struktur modal perusahaan dalam tahapan tumbuh

\section{Risiko Bisnis \& Struktur}

Dalam penelitian Harjanti \& Tandelilin (2007) berpendapat bahwa risiko bisnis perusahaan dapat digambarkan dengan mengukur fluktuasi dari laba perusahaan. Perusahaan yang mengalami fluktuasi laba menghadapai ketidakpastian kemampuan dalam hal mengumpulkan dana untuk melunasi pinjamannya kepada kreditur. Oleh karena itu perusahaan yang memiliki risiko bisnis yang tinggi akan berusaha menjaga proksi hutangnya agar tidak membahayakan going concern perusahaan. Risiko bisnis merupakan risiko dari perusahaan saat tidak mampu menutup biaya operasionalnya dan dipengaruhi oleh stabilitas pendapatan dan biaya (Gitman 2009). Pada dasarnya, semakin besar risiko bisnis yang dihadapi perusahaan akan memperkecil rasio penggunaan hutang, untuk menghindari risiko yang berlebihan yang disebabkan oleh penggunaan hutang sehingga dapat dikatakan bahwa risiko berpengaruh negatif terhadap struktur modal.

H2 : Risiko bisnis berpengaruh negatif terhadap struktur modal

\section{Diversifikasi dan Nilai Perusahaaan}

Diversifikasi merupakan bentuk pengembangan usaha dengan cara memperluas jumlah segmen secara bisnis maupun geografis maupun memperluas market share yang ada atau mengembangkan berbagai produk yang beraneka ragam. Kochhar \& Hitt (1998) menguji hungan antara tipe diversifikasi dan strategi pendanaan perusahaan. Hasil penelitian tersebut menyatakan bahwa pendanaan dengan ekuitas lebih disukai untuk perusahaan yang related diversification, sedangkan unrelated diversification berhubungan dengan pendanaan hutang.

Berdasarkan penjelasan biaya ekonomis transaksi, perusahaan melakukan diversifikasi karena masih memiliki kelebihan sumberdaya. Kelebihan specific asset memungkinkan 


\section{Septi Diana Sari}

perusahaan melakukan related diversification, sementara kelebihan non-specific asset berhubungan dengan strategi unrelated diversification. Strategi unrelated diversification menunjukan adanya kelebihan non-specific asset perusahaan (Mahoney \& Pandeyan 1992) Karena keputusan pendanaan perusahaan tergantung pada aset perusahaan, sehingga memungkinkan hubungan antara diversifikasi dan struktur modal. Perbedaan tingkat spesifikasi aset menjelaskan adanya perbedaan preferensi pendanaan pada tiap strategi diversifikasi.

H3: Struktur modal unrelated diversification firms lebih besar dibandingkan struktur modal related diversification firm, struktur modal related diversification firms lebih besar dibandingkan single segmen firms

\section{Struktur Modal \& Nilai Perusahaan}

Trade off theory menjelaskan bahwa peningkatan hutang pada struktur modal akan meningkatkan nilai perusahaan sebesar tarif pajak dikali dengan jumlah hutang. Struktur modal optimal dapat diperoleh dengan adanya keseimbangan antara keuntungan tax shield dengan financial distress dan agency cost, karena penggunaan leverage. Dengan kata lain terjadi trade-off antara benefit dengan biaya. Financial distress terjadi jika perusahaan mengalami kesulitan dalam melunasi kewajiban hutangnya, dimana perusahaan terancam kebangkrutan Karena itu financial distress perlu diperhitungkan karena mengurangi nilai perusahaan

Hasnawati (2005) hasil penelitiannya menunjukan bahwa keputusan pendanaan berpengaruh positif terhadap nilai perusahaan. Sriwardany (2006) dalam penelitiannya menguji pengaruh pertumbuhan perusahaan terhadap harga saham dengan struktur modal sebagai variabel intervening, ditemukan bahwa struktur modal berpengaruh negatif terhadap harga saham dengan kata lain perusahaan yang menggunakan lebih banyak hutang maka nilai perusahaan akan turun. Safrida (2008) juga menguji pengaruh struktur modal dan pertumbuhan perusahaan terhadap nilai perusahaan. Hasilnya menunjukkan bahwa struktur modal dan pertumbuhan perusahaan berpengaruh terhadap nilai perusahaan. Nanok (2008) menyatakan bahwa struktur modal akan menentukan sejauh mana, bagaimana nilai diciptakan yang akan tercermin dari laba dan harga saham perusahaan.

H4 : Struktur modal berpengaruh negatif dan signifikan terhadap nilai perusahaan

\section{Diversifikasi dan Nilai Perusahaan}

Dalam literatur keuangan, teori keagenan (agency theory) memegang peranan penting dalam menjelaskan hubungan antara prinsipal dan agen dalam menjalankan fungsi dan 
wewenang masing-masing. Konflik keagenan yang muncul karena perbedaan kepentingan akan membawa pada masalah-masalah diantara berbagai pihak yang terlibat (Jensen dan Meckling 1976). Dalam konteks konflik kepentingan tersebut, maka diversifikasi sebagai kebijakan perusahaan menjadi kurang optimal. Manager yang melakukan diversifikasi akan mengarahkan diversifikasi sesuai dengan kepentingannya. Hal ini antara lain kinerja manajerial dikaitkan dengan tingkat penjualan, sehingga diversifikasi menjadi alat yang efektif untuk meningkatkan omset perusahaan. Padahal investasi tersebut tidak memberikan hasil net present value yang menggembirakan. Akibatnya diversifikasi yang dilakukan oleh perusahaan justru mengurangi nilai perusahaan. Fenomena ini disebut pula sebagai diversification discount.

Banyak penelitian yang mencoba menguji secara empiris pengaruh diversifikasi perusahaan terhadap kinerja perusahaan. Comment dan Jarrell (1994) menemukan hubungan yang negatif antara return saham abnormal dengan beberapa ukuran diversifikasi. Ukuran yang dipakai meliputi jumlah segmen yang dilaporkan, serta indeks Herfindahl berbasis aset dan pendapatan. Hasil yang serupa diperoleh Lang dan Stulz (1994) yang melaporkan hubungan negatif antara rasio Tobin's q dan ukuran-ukuran diversifikasi. Berger dan Ofek (1995) menunjukkan bahwa nilai perusahaan yang terdiversifikasi lebih kecil dibanding perusahaan yang beroperasi pada segmen tunggal. Selisih nilai (value loss) berkisar antara 13\%-15\%, dimana selisih nilai akan berkurang jika perusahaan melakukan diversikasi pada segmen yang berkaitan (related diversification).

H5 : Nilai perusahaan single segment lebih besar dibandingkan nilai perusahaan Related dan unrelated Diversification

\section{METODE PENELITIAN}

\section{Populasi dan Sampel Penelitian}

Sampel dari penelitian ini adalah perusahaan yng berada dalam industri manufaktur yang terdaftar di Bursa Efek Indonesia (BEI) periode 2009-2012. Pendekatan pengambilan sampel yang digunakan adalah nonprobability sampling yaitu desain pengambilan yang tidak acak dan subyektif. Dengan tipe desain sampel adalah purposive sampling yaitu berdasarkan tujuan dan dengan kriteria-kriteria yang ditetapkan. Diantaranya, sudah go public, mencantumkan laporan keuangan secara rutin dari tahun 2009-2012.

\section{Jenis dan Sumber Data}

Data yang digunakan dalam penelitian ini adalah data sekunder yaitu nilai buku 


\section{Septi Diana Sari}

hutang dan ekuitas, penjualan, EBIT, closing price, jumlah saham beredar, liablities, persediaan, current asset, total aset, laba bersih, SIC 3 digit. Sumber data berasal dari laporan keuangan tahunan dan OSIRIS.

\section{Definisi Operasional \& Pengukuran Variabel}

Struktur Modal

Struktur modal adalah gabungan dari berbagai sumber pendanaan, dengan kategori utamanya adalah hutang dan ekuitas yang digunakan perusahaan untuk mendanai investasi asetnya. Dalam penelitian ini, struktur modal diukur dengan rumus berikut:

$\mathrm{DER}=\frac{\text { Nillaĭ Buku Total Hutang }}{\text { Ekuitas }}$

Firms Life Cycle

Pengelompokan kedalam tahapan siklus ini didasarkan atas tingkat pertumbuhan penjualan (Gup \& Agrrawal 1996). Berikut tabel tingkat pertumbuhan penjualan sepanjang tahapan hidup perusahaan

Tabel 2. Tingkat pertumbuhan penjualan sepanjang tahapan hidup perusahaan

\begin{tabular}{ccc}
$\begin{array}{c}\text { Kelompok } \\
\text { penjualan }\end{array}$ & Tahap Hidup & $\begin{array}{c}\text { Rata-rata tingkat } \\
\text { pertumbuhan }\end{array}$ \\
\hline 1 & start-up & diatas $50 \%$ \\
2 & growth & $20-49,9 \%$ \\
3 & growth/mature & $10-19,9 \%$ \\
4 & mature & $0-9,9 \%$ \\
5 & decline & dibawah 0\% \\
\hline \multicolumn{3}{c}{ Sumber : Gup \& Agrawal, 1996}
\end{tabular}

Terdapat lima kategori dalam pengukuran Siklus Hidup Perusahaan, oleh karena itu peneliti menggunakan empat Dummy (k-1) yaitu DFLC1 (start-up), DFLC2 (growth), DFLC3 (growth/mature), DFLC4 (mature). Semua responden yang menjadi anggota kategori yang diberi kode 1 sedangkan responden tidak dalam kategori tersebut dikode dari 0 .

Risiko Bisnis

Dalam mengukur risiko bisnis penulis menggunakan koefesien variasi laba operasi yang merupakan deviasi standar laba operasi dibagi dengan laba operasi yang diharapkan (laba operasi rat-rata) (Home \& Wachowicz 2005). 
Risiko Bisnis $=\frac{\text { Deviasi Standar Laba Operasi }}{\text { Laba Operasi Diharapkan }}$

Diversifikasi

Diversifikasi perusahaan merupakan tingkat pengembangan yang dilakukan perusahaan melalui jumlah perusahaan yang dikelola maupun tingkat segmen usaha yang dimiliki. Perusahaan yang memiliki minimal dua segmen usaha dikelompokan kedalam diversifikasi. Jika perusahaan yang terdiversifikasi tersebut memiliki dua sic 3 digit yang berbeda, maka dikelompokan kedalam unrelated diversification. Namun, jika antar satu segmen dengan segmen lainnya memiliki angka 3 digit pertama yang sama maka digolongkan kedalam related diversification firms. Perusahaan yang hanya memiliki satu segmen bisnis digolongkan kedalam single segmen firms.

Nilai Perusahaan

Nilai perusahaan dalam penelitin ini diukur dengan menggunakan rasio pasar yaitu Price Book Value (PBV). dengan persamaan sebagai berikut:

$$
\text { PBV }=\frac{\text { Nilai pasar saham }}{\text { Nilail Buku Saham }}
$$

\section{Perumusan Model}

Analisis yang digunakan dalam penelitian ini adalah analisis regresi berganda terhadap data panel. Untuk menguji hipotesis 1,2 dan 3 digunakan persamaan (model 1):

$\mathrm{DER}=\alpha+\beta_{1} \mathrm{DDiv} \cdot \mathrm{R}+\beta_{2}$ DDiv. UR $+\beta_{9}$ DFLC1 $+\beta_{4} \mathrm{DFLC} 2+\beta_{5} \mathrm{DFLC} 3+\beta_{6} \mathrm{DDFLC} 4+\beta_{7}$ Risk $+e$

Untuk menguji hipotesis 4 dan 5 (model 2) digunakan persamaan sebagai berikut:

$\mathrm{PBV}=\alpha+\beta_{1} \mathrm{DDiv} \cdot \mathrm{R}+\beta_{2} \mathrm{DDiv} \cdot \mathrm{UR}+\beta_{\mathrm{g}} \mathrm{DER}+\mathrm{e}$

Hipotesis 1 terdukung apabila koefesie $\beta_{5}$ pada persamaan regresi diatas (model 1 ) bernilai positif signifikan dan lebih besar dari pada $\beta_{4^{x}}$ Sedangkan hipotesis 2 terdukung jika $\beta_{8}$ bernilai negatif. Hipotesis 3 terdukung jika nilai koefesien $\beta_{2}$ dam $\beta_{1}$ bernilai positif signifikan, dimana $\beta_{2}>\beta_{1}$ dan $\beta_{1}>\alpha$. Hipotesis 4 terdukung apabila koefesien $\beta_{a}$ pada persamaan regresi diatas (model 2) bernilai negatif signifikan. Hipotesis 3 terdukung jika nilai koefesien $\beta_{1}$ dam $\beta_{2}$ bernilai positif signifikan, dimana angka $\alpha>\beta_{1}>\beta_{2}$. Seluruh hipotesis 


\section{Septi Diana Sari}

tersebut diuji dengan menggunakan tingkat kepercayaan sebesar $95 \%$ atau a $5 \%$.

\section{PEMBAHASAN DAN KESIMPULAN}

Hasil Uji Hipotesis 1, 2 dan 3

Tabel 4. Hasil Regresi Model 1

(Variabel dependent: Struktur Modal (DER))

\begin{tabular}{|l|l|l|}
\hline Variabel & Nilai & Sig \\
\hline Constant & 0.374 & 0,019 \\
D. Div.R & 0,615 & 0,003 \\
D.Div.UR & 0,532 & 0,004 \\
D. FLC1 & 0,693 & 0,018 \\
D.FLC2 & 0,126 & 0,555 \\
D.FLC3 & $-0,054$ & 0,798 \\
D.FLC4 & $-0,010$ & 0,965 \\
Risk & 0,890 & 0.000 \\
Adj. R Square & 0,450 & \\
F & 54,967 & 0,000 \\
\hline
\end{tabular}

Sumber : Data Diolah

Berkaitan dengan siklus hidup perusahaan, secara statistik hanya perusahaan yang berada pada tahap start-up yang berpengaruh signifikan terhadap struktur modal. Dimana perusahaan yang berada pada tahap start-up tersebut memiliki tingkat pertumbuhan penjualan rata-rata terbesar dibanding perusahaan dalam tahapan lainnya yaitu sebesar 50\%. Sehingga dapat dikatakan bahwa hipotesis 1 tidak terdukung. Perusahaan yang berada pada tahap start-up tersebut berpengaruh positif dengan nilai koefesien 0,693 terhadap struktur modal secara signifikan (prob. Valve $=0,018$ ), sehingga dapat dinyatakan bahwa perusahaan yang berada pada tahap start-up memiliki proporsi hutang terhadap ekuitasnya yang relatif besar dibanding perusahaan dalam tahap lainnya yaitu tahap declining. Hasil uji hipotesis 1 tersebut bertentangan dengan pernyataan Hovakimian, Opler \& Titman (2001) bahwa perusahaan sebaiknya menggunakan lebih banyak utang untuk mendanai aset yang ada dan lebih banyak ekuitas untuk mendanai kesempatan tumbuh.

Hal ini dapat dijelaskan bahwa pertumbuhan perusahaan pada dasarnya mencerminkan produktivitas perusahaan. Brigham \& Houston (2001) menyatakan bahwa perusahaan yang tumbuh dengan pesat akan lebih banyak mengandalkan modal eksternal. Damodaran (2001) menyatakan bahwa pada tahap pertumbuhan tinggi, perusahaan menjadi perusahaan publik dimana sumber dana banyak berasal dari eksternal. Berdasarkan teori 
pecking order perusahaan lebih senang menggunakan sumber dana internal, jika sumber intenal belum memadai perusahaan akan mencari dana eksternal dengan mengutamakan hutang terlebih dahulu baru kemudian menerbitkan saham.

Variabel risiko dalam model 1 tersebut mempunyai pengaruh positif dengan nilai koefesien 0,890 dan signifikan (prob value $=0,00$ ). Sehingga dapat dinyatakan bahwa hipotesis 2 terdukung. Pengaruh positif risiko terhadap struktur modal dalam penelitian ini dapat dijelaskan dengan signaling effect, dimana semakin besar risiko, perusahaan akan berusaha menggunakan sumber dana dari utang untuk membagi risiko dengan kreditur.

Hipotesis 3 dalam penelitian ini terdukung sebagian dimana perusahaan yang terdiversifikasi akan memiliki struktur modal yang lebih besar dibandingkan single segmen firms, hal ini ditunjukan dengan nilai koefesien pada DDiv.R dan Ddiv.UR masing-masing memiliki koefesien positif dan signifikan, Namun struktur modal unrelated diversification firms $(0,532)$ lebih kecil dibanding struktur modal related diversification firms $(0,615)$. Hal ini bertentangan dengan hasil penelitian Kochhar \& Hitt (1998) yang menyatakan bahwa perusahaan yang related diversification lebih menyukai pendanaan dengan utang, sedangkan perusahaan yang unrelated diversification berhubungan dengan pendanaan utang, serta Bergh (1997) yang menyatakan bahwa perusahaan yang melakukan unrelated diversification lebih mampu menerbitkan utang, karena unrelated diversification akan mengurangi risiko perusahaan.

Strategi diversifikasi perusahaan berhubungan dengan risiko dan return yang diterima manajer dan pemilik, dimana pada umumnya perusahaan yang tidak melakukan diversifikasi (single segment) umumnya memiliki risiko yang lebih besar dibanding perusahaan yang terdiversifikasi karena adanya coinsurance effect, sehingga perusahaan yang terdiversifikasi dapat meningkatkan kapasitas utangnya (perusahaan yang terdiversifikasi lebih mampu menerbitkan utang). Nilai koefesien unrelated diversification firms yang lebih kecil dibanding related diversification firms, kemungkinan disebabkan karena adanya mekanisme pasar internal antar bisnis unit dalam unrelated diversification firms. Hal ini juga sesuai dengan pecking order theory yang menyatakan bahwa perusahaan lebih menyukai pendanaan internal dibandingkan pendanaan eksternal. 


\section{Septi Diana Sari}

Hasil Uji Hipotesis 4 \& 5

Tabel 5. Hasil Regresi Model 2

(Variabel Dependent: Nilai Perusahaan (PBV))

\begin{tabular}{|l|l|l|}
\hline Variabel & Nilai & Sig \\
\hline Constant & 0,689 & 0,001 \\
D. Div.R & 0,920 & 0,020 \\
D.Div.UR & 0,222 & 0.521 \\
DER & 0,898 & 0,000 \\
Adj. R Square & 0,297 & \\
F & 66,990 & 0,000 \\
\hline
\end{tabular}

Sumber : Data Diolah

Struktur modal secara signifikan (prob.value $=0,000$ ) berpengaruh positif terhadap nilai perusahaan dengan nilai koefesien sebesar 0,896, sehingga $\mathrm{H} 4$ tidak terdukung. Hal ini menunjukan adanya signalling effect yaitu peningkatan utang perusahaan diartikan oleh investor bahwa perusahaan memiliki peluang pertumbuhan yang bagus dan pada akhirnya dapat meningkatkan nilai perusahaan.

Strategi related diversification perusahaan secara signifikan (prob. Value $=0,020$ ) berpengaruh positif terhadap nilai perusahaan dengan nilai koefesien 0,920, menunjukan bahwa nilai perusahaan dengan related diversification lebih besar dibanding nilai perusahaan single segment, serta unrelated diversification firms tidak memiliki pengaruh yang signifikan terhadap nilai perusahaan (Hipotesis 5 tidak terdukung). Pengaruh langsung related diversification firms terhadap nilai perusahaan lebih besar (koefesien D.DivR $=0,920$ ) dibandingkan pengaruh secara tidak langsung melalui mediasi struktur modal sebesar 0,552 $(0,615 \times 0,0898)$, begitu juga dengan pengaruh langsung single segment firms terhadap nilai perusahaan lebih besar (konstanta model $2=0,689$ ) dibandingkan pengaruh secara tidak langsung melalui struktur modal yaitu sebesar 0,336 $(0,374 \times 0,898)$.

\section{KESIMPULAN}

Dari uraian diatas dapat disimpulkan bahwa berkaitan dengan siklus hidup perusahaan hanya perusahaan yang berada pada start-up yang berpengaruh positif dan signifikan 
terhadap struktur modal, Risiko bisnis berpengaruh positif terhadap struktur modal, serta strategi diversifikasi berpengaruh terhadap struktur modal, dimana struktur modal perusahaan dengan related diversification > struktur modal unrelated diversification > struktur modal single segment. Namun ketika strategi diversifikasi diregresikan dengan nilai perusahaan, hanya strategi single segment dan related diversification yang berpengaruh secara signifikan terhadap nilai perusahaan, serta struktur modal berpengaruh positif terhadap nilai perusahaan. Sebagian besar dari hasil penelitian ini dapat dijelaskan dengan signalling effect dan pecking order theory.

\section{IMPILIKASI DAN KETERBATASAN}

Hasil penelitian ini diharapkan dapat memberikan kontribusi pada perkembangan ilmu pengetahuan khususnya di bidang manajemen keuangan. Penelitian ini juga diharapkan dapat menjadi acuan bagi peneliti selanjutnya,dan dapat dikembangkan dengan menguji lebih lanjut strategi diversifikasi unrelated dengan mempertimbangkan korelasi positif atau negatif antar unit bisnis perusahaan dan dikaitkan dengan nilai perusahaan, serta memperbanyak sampel, misalnya seluruh perusahaan yang terdaftar di Indonesia atau membandingkan hasil penelitian dengan menggunakan data-data perusahaan di beberapa negara di ASIA, serta dapat diaplikasikan kedalam lingkup yang lebih kecil misalnya perusahaan manufaktur kecil yang terdapat pada daerah tertentu.

\section{DAFTAR PUSTAKA}

Abor, J (2007), "Debt Policy and Performance of SMEs: Evidence From Ghanaian and South African Firms," The Journal of Risk Finance, Vol. 8, No. 4, pp. 364-378

Adizes, I. 2004. 'Adizes - Resources for sustainable exceptional performance'. [online] URL: www.adizes.com

Alonso, Eduardus. 2000. The Effect Of Firm Diversification on Capital Structure: Evidence From Spanish Firms. European Financial Management Association Annual Meeting

Akintoye, I.R (2008), "Sensitivity of Performance to Capital Structure," European Journal of Social Science, Vol. 7, No. 1, pp. 23-31

Bender, R. And Ward. K. 1993. "Corporate Financial Strategy. Oxford: Butterworth-Heinemann

Berger, P. G., and Ofek, E. 1995. Diversification's effect on firm value. Journal of Financial Economics, 37, 39-65

Brigham, E.F. dan M.C. Ehrhardt, 2005, Financial Management : Theory and Practices, SouthWestern, Thomson, $11^{\text {th }}$ edition 


\section{Septi Diana Sari}

Comment, R., and Jarrell, G. A. 1994. Corporate focus and stock returns. Journal of Financial Economics, 37, 67-87.

Damodaran, A. 2001. Corporate finance: Theory and practice. New York: John Wiley and Sons

Fama, E. and K. French, (2005), "Financing Decisions: Who Issues Stock?" Journal of Financial Economics, 76, pp.549-82

Frank, Murray Z., and Vidhan K. Goyal, 2009, Capital structure decisions: which factors are reliably important? Financial Management 38, 1-37.e Analysis 36, 1-24.

Frielinghaus, B. Mostert \& C. Firer. 2005. "Capital Structure and The Firm's Life Stage". Graduate School of Business University of Cape Town

Gamba. A \& A. Triantis (2008). "The Value of Financial Flexibility," The Journal of Finance, Vol LXIII, No. 5, pp. 2263-2296

Gitman, Lawrence. 2009. Principles of Managerial Finance 11 th edition. Prentice Hall

Gup, Benton E., \& P. Agrawal, 1996. "The Product Life Cycle: A Paradigm for Understanding Financial Management," Financial Practice and Education, pp 41-48n

Hanafi, Mamduh. 2004. Manajemen Keuangan Ed.1, BPFE, Yogyakarta

Harjanti, Theresia T \& Eduardus Tandelilin. 2007. Pengaruh Firm Size, Tangible Asset, Growth, Profitability \& Business Risk Pada Struktur Modal Perusahaan Manufaktur di Indonesia: Studi Kasus di BEJ. Jurnal Ekonomi \& Bisnis, Vol. 1 No. 1 hlm 1-10

Hasnawati, Sri. 2005. "Implikasi Kpetusan Investasi, Pendanaan dan Deviden Terhadap Nilai Perusahaan Publik Di Bursa Efek Jakarta". Usahawan: No. 09/Th XXXIX, September 2005

Horne., J.C \& Wachowicz JRJ . 2005. Fundamental Of Financial Management, 12th Ed. NewJersey. Prentice-Hall,Inc

Jensen, M., and W. Meckling. 1976. The theory of the firm: Managerial behavior, agency costs, and ownership structure, Journal of Financial Economics, 3, 305-60.

Kochhar. R \& Hitt M. 1998. "Lingking Corporate Strategy Capital Structure: Diversification Strategy, Type and Source Of Financing". Sttrategic Management Journal. Vol. 17. Pp. 713-728

Lang, L.H.P., and R.E. Stulz. 1994. Tobin's Q, Corporate Diversification and Firm Performance, Journal of Political Economy, Vol. 102, No.6, 1248-1280.

Mahoney J. T \& Pandian. J.R. 1992."The Resource-Based View Within The Conversation of Strategic Management". Strategic Management Journal. Vol. 13. Pp. 363-380

Nanok, Yanuar. 2008. Capital Structure Determinan di Indonesia. Akuntabilitas, Maret hlm $122-127$

Parsons, Christopher A., and Sheridan Titman, 2008, Empirical capital structure: a review Foundationsand Trends in Finance 3, 1-93. 
Safrida: 2008. Pengaruh Struktur Modal dan Pertumbuhan Perusahaan Terhadap Nilai Perusahaan pada Perusahaan Manufaktur di Bursa Efek Jakarta, Tesis Program Pasca Sarjana Universitas Sumtera Utara. ejurnal.stiedharmaputra-smg.ac,id

Sriwardany. 2006. "Pengaruh Pertumbuhan Perusahaan Terhadap Kebijakan Struktur Modal dan Dampaknya Terhadap Perubahan Harga Saham Pada Perusahaan Manufaktur di BEJ"

Suwarno, F.X. dan S.I. Ediningsih, 2002, Pengaruh Stabilitas Penjualan Struktur Aktiva, Tingkat Pertumbuhan Dan Profitabilitas Terhadap Struktur Modal Pada Perusahaan Perdagangan Eceran Di Bursa Efek Jakarta, Jurnal Akuntansi, Tahun VI. No. 1. Mei. Hal. $20-32$.

Stewart, G.B. 1999. The quest for value - A guide for senior managers. New York:Harper Business.

\section{LAMPIRAN 1. OUTPUT MODEL 1}

Model Summary

\begin{tabular}{|l|r|r|r|r|}
\hline Model & $R$ & R Square & \multicolumn{1}{c|}{$\begin{array}{c}\text { Adjusted R } \\
\text { Square }\end{array}$} & $\begin{array}{c}\text { Std. Error of the } \\
\text { Estimate }\end{array}$ \\
\hline 1 & .6719 & .450 & .441 & 1.65227 \\
\hline
\end{tabular}

a. Predictors: (Constant), Risk, FLC2, Div.R, FLC1, Div.UR,

FLC4, FLC3

ANOVAb

\begin{tabular}{|c|c|c|c|c|c|}
\hline Model & Sum of Squares & $\mathrm{df}$ & Mean Square & $\mathrm{F}$ & Sig. \\
\hline Regression & 1050.408 & & 150.058 & 54.967 & $.000^{\circ}$ \\
\hline Residual & 1285.828 & 471 & 2.730 & & \\
\hline Total & 2336.236 & 478 & & & \\
\hline
\end{tabular}

a. Predictors: (Constant), Risk, FLC2, Div.R, FLC1, Div.UR, FLC4, FLC3

b. Dependent Variable: DER

Coefficientsa

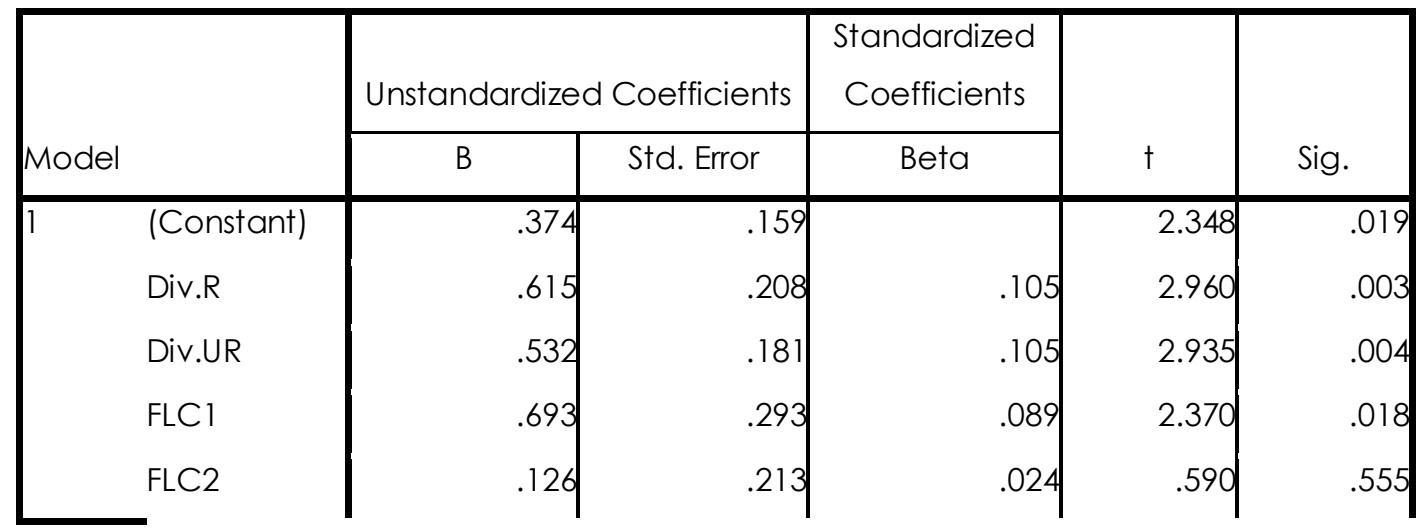


Septi Diana Sari

\begin{tabular}{|c|c|c|c|c|}
\hline FLC3 & -.054 & .212 & -.010 & -.256 \\
\hline FLC4 & -.010 & .234 & -.002 & -.044 \\
\hline Risk & .890 & .048 & .640 & 18.359 \\
\hline
\end{tabular}

a. Dependent Variable: DER

LAMPIRAN 2. OUTPUT MODEL 2

Model Summary

\begin{tabular}{|r|r|r|r|r|}
\hline Model & $R$ & R Square & \multicolumn{1}{c|}{$\begin{array}{c}\text { Adjusted R } \\
\text { Square }\end{array}$} & $\begin{array}{c}\text { Std. Error of the } \\
\text { Estimate }\end{array}$ \\
\hline 1 & .5450 & .297 & .293 & 3.13867 \\
\hline
\end{tabular}

a. Predictors: (Constant), DER, Div.R, Div.UR

ANOVAb

\begin{tabular}{|c|c|c|c|c|c|}
\hline Model & Sum of Squares & $d f$ & Mean Square & $\mathrm{F}$ & Sig. \\
\hline Regression & 1979.808 & 3 & 659.936 & 66.990 & $.000^{\circ}$ \\
\hline Residual & 4679.344 & 475 & 9.851 & & \\
\hline Total & 6659.152 & 478 & & & \\
\hline
\end{tabular}

a. Predictors: (Constant), DER, Div.R, Div.UR

b. Dependent Variable: PBV

Coefficientsa

\begin{tabular}{|c|c|c|c|c|c|c|}
\hline \multirow{2}{*}{\multicolumn{2}{|c|}{ Model }} & \multicolumn{2}{|c|}{ Unstandardized Coefficients } & \multirow{2}{*}{$\begin{array}{l}\text { Standardized } \\
\text { Coefficients } \\
\text { Beta }\end{array}$} & \multirow[b]{2}{*}{$\dagger$} & \multirow[b]{2}{*}{ Sig. } \\
\hline & & B & Std. Error & & & \\
\hline \multirow[t]{4}{*}{1} & (Constant) & .689 & .204 & & 3.377 & .001 \\
\hline & Div.R & .920 & .394 & .093 & 2.335 & .020 \\
\hline & Div.UR & .222 & .345 & .026 & .642 & .521 \\
\hline & DER & .898 & .065 & .532 & 13.710 & .000 \\
\hline
\end{tabular}

a. Dependent Variable: PBV

LAMPIRAN 3. STATISTIK DESKRIPTIF \& UJI ASUMSI KLASIK

Descriptive Statistics

\begin{tabular}{|l|r|r|r|r|r|}
\hline & $\mathrm{N}$ & Minimum & Maximum & Mean & Std. Deviation \\
\hline Div.R & 479 & .00 & 1.00 & .1733 & .37888 \\
Div.UR & 479 & .00 & 1.00 & .2526 & .43496 \\
DER & 479 & .08 & 39.79 & 1.4002 & 2.21077 \\
\hline
\end{tabular}




\begin{tabular}{|c|c|c|c|c|c|}
\hline IPBV & 479 & .13 & 49.82 & 2.1617 & 3.73246 \\
\hline $\mathrm{FLCl}$ & 479 & .00 & 1.00 & .0877 & .28313 \\
\hline FLC2 & 479 & .00 & 1.00 & .2255 & .41833 \\
\hline FLC3 & 479 & .00 & 1.00 & .2338 & .42370 \\
\hline FLC4 & 479 & .00 & 1.00 & .1649 & .37150 \\
\hline Risk & 479 & .03 & 28.17 & .7978 & 1.58939 \\
\hline Valid N (listwise) & 479 & & & & \\
\hline
\end{tabular}
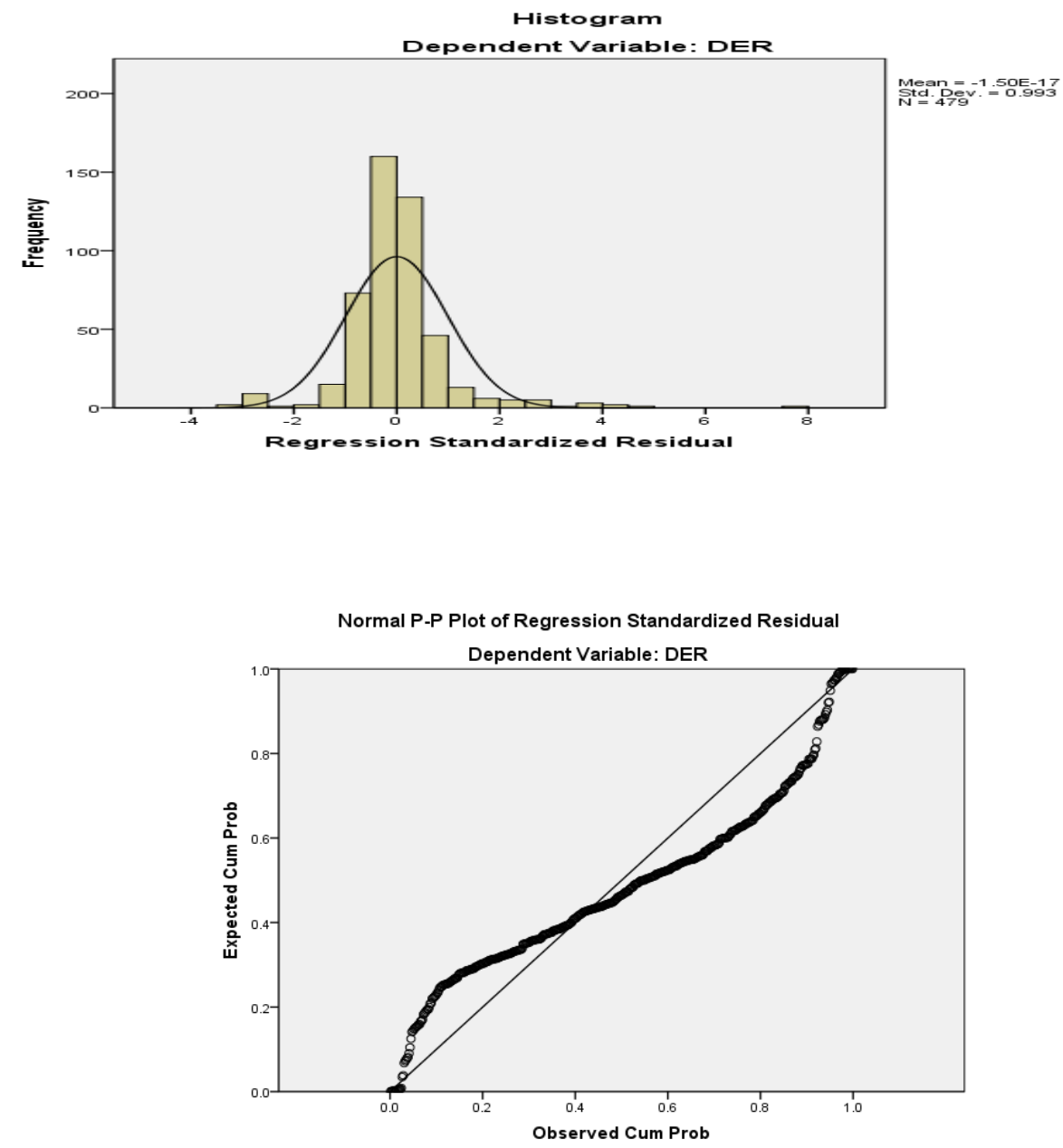

Variables Entered/Removedb

\begin{tabular}{|l|l|l|l|}
\hline Model & Variables Entered & $\begin{array}{c}\text { Variables } \\
\text { Removed }\end{array}$ & Method \\
\hline 1 & $\begin{array}{l}\text { Risk, FLC2, Div.R, FLCl, } \\
\text { Div.UR, FLC4, FLC3 }\end{array}$ & & Enter \\
\hline
\end{tabular}

a. All requested variables entered.

b. Dependent Variable: abresid

Model Summaryb 
Septi Diana Sari

\begin{tabular}{|l|r|r|r|r|}
\hline Model & $R$ & $R$ Square & $\begin{array}{l}\text { Adjusted R } \\
\text { Square }\end{array}$ & $\begin{array}{c}\text { Std. Error of the } \\
\text { Estimate }\end{array}$ \\
\hline 1 & $.635^{\circ}$ & .403 & .394 & 1.00984 \\
\hline
\end{tabular}

a. Predictors: (Constant), Risk, FLC2, Div.R, FLC1, Div.UR, FLC4, FLC3

b. Dependent Variable: abresid

ANOVAb

\begin{tabular}{|ll|r|r|r|r|r|}
\hline Model & Sum of & Squares & df & Mean Square & $F$ & Sig. \\
\hline 1 & Regression & 324.725 & 7 & 46.389 & 45.490 & .0009 \\
& Residual & 480.311 & 471 & 1.020 & & \\
& Total & 805.036 & 478 & & & \\
\hline
\end{tabular}

a. Predictors: (Constant), Risk, FLC2, Div.R, FLC1, Div.UR, FLC4, FLC3

b. Dependent Variable: abresid

Coefficientsa

\begin{tabular}{|c|c|c|c|c|c|c|}
\hline \multirow[b]{2}{*}{ Model } & & \multicolumn{2}{|c|}{ Unstandardized Coefficients } & \multirow{2}{*}{$\begin{array}{c}\text { Standardized } \\
\text { Coefficients }\end{array}$} & \multirow[b]{2}{*}{$\dagger$} & \multirow[b]{2}{*}{ Sig. } \\
\hline & & B & Std. Error & & & \\
\hline 1 & (Constant) & .582 & .097 & & 5.975 & .00 \\
\hline & Div.R & .384 & .127 & .112 & 3.024 & .003 \\
\hline & Div.UR & .378 & .111 & .127 & 3.414 & .00 \\
\hline & $\mathrm{FLCl}$ & .240 & .179 & .052 & 1.341 & .181 \\
\hline & FLC2 & -.140 & .130 & -.045 & -1.075 & .283 \\
\hline & FLC3 & -.335 & .130 & -.109 & -2.585 & .010 \\
\hline & FLC4 & -.210 & .143 & -.060 & -1.469 & .142 \\
\hline & Risk & .478 & .030 & .585 & 16.117 & .000 \\
\hline
\end{tabular}

a. Dependent Variable: abresid

Residuals Statisticsa

\begin{tabular}{|l|r|r|r|r|r|}
\hline & Minimum & Maximum & Mean & Std. & Deviation \\
& $\mathrm{N}$ \\
\hline Predicted Value & .2760 & 14.6524 & 1.0019 & .82422 & 479 \\
Residual & -2.19008 & 6.49643 & .00000 & 1.00241 & 479 \\
Std. Predicted Value & -.881 & 16.562 & .000 & 1.000 & 479 \\
Std. Residual & -2.169 & 6.433 & .000 & .993 & 479 \\
\hline
\end{tabular}

a. Dependent Variable: abresid

Variables Entered/Removedb 


\begin{tabular}{|l|l|l|l|}
\hline Model & Variables Entered & $\begin{array}{l}\text { Variables } \\
\text { Removed }\end{array}$ & Method \\
\hline 1 & $\begin{array}{l}\text { Risk, FLC2, Div.R, } \\
\text { FLC1, Div.UR, FLC4, } \\
\text { FLC3 }\end{array}$ & & \\
& & & \\
\hline
\end{tabular}

a. All requested variables entered.

b. Dependent Variable: DER

Coefficientsa

\begin{tabular}{|ll|r|r|}
\hline \multirow{2}{*}{ Model } & \multicolumn{2}{|c|}{ Collinearity Statistics } \\
\cline { 3 - 4 } & & \multicolumn{1}{|c|}{ Tolerance } & \multicolumn{1}{c|}{ VIF } \\
\hline 1 & Div.R & .921 & 1.086 \\
& Div.UR & .917 & 1.090 \\
& FLC1 & .832 & 1.202 \\
& FLC2 & .721 & 1.387 \\
& FLC3 & .708 & 1.412 \\
& FLC4 & .756 & 1.324 \\
& Risk & .962 & 1.039 \\
\hline
\end{tabular}

a. Dependent Variable: DER

Coefficient Correlationsa

\begin{tabular}{|c|c|c|c|c|c|c|c|c|}
\hline \multicolumn{2}{|l|}{ Model } & Risk & FLC2 & Div.R & $\mathrm{FLCl}$ & Div.UR & FLC4 & FLC3 \\
\hline \multirow[t]{7}{*}{ Correlations } & Risk & 1.000 & .047 & .038 & -.099 & -.054 & .062 & .103 \\
\hline & FLC2 & .047 & 1.000 & -.026 & .312 & .031 & .402 & .443 \\
\hline & Div.R & .038 & -.026 & 1.000 & .012 & .266 & -.061 & -.053 \\
\hline & $\mathrm{FLCl}$ & -.099 & .312 & .012 & 1.000 & .001 & .282 & .308 \\
\hline & Div.UR & -.054 & .031 & .266 & .001 & 1.000 & -.025 & -.073 \\
\hline & $\mathrm{FLC} 4$ & .062 & .402 & -.061 & .282 & -.025 & 1.000 & .409 \\
\hline & FLC3 & .103 & .443 & -.053 & .308 & -.073 & .409 & 1.000 \\
\hline \multirow[t]{7}{*}{ Covariances } & Risk & .002 & .000 & .000 & -.001 & .000 & .001 & .001 \\
\hline & FLC2 & .000 & .045 & -.001 & .019 & .001 & .020 & .020 \\
\hline & Div.R & .000 & -.001 & .043 & .001 & .010 & -.003 & -.002 \\
\hline & $\mathrm{FLCl}$ & -.001 & .019 & .001 & .086 & $3.204 \mathrm{E}-5$ & .019 & .019 \\
\hline & Div.UR & .000 & .001 & .010 & $3.204 \mathrm{E}-5$ & .033 & -.001 & -.003 \\
\hline & $\mathrm{FLC4}$ & .001 & .020 & -.003 & .019 & -.001 & .055 & .020 \\
\hline & FLC3 & 001 & .020 & -.002 & 019 & -003 & $02 d$ & 04 \\
\hline
\end{tabular}

a. Dependent Variable: DER 
Septi Diana Sari 